DOI https://doi.org/10.30525/978-9934-26-040-7-41

\title{
СУЧАСНИЙ СТАН ЗАКОНОДАВЧОГО РЕГУЛЮВАННЯ ЕЛЕКТРОННОГО СПОРТУ В УКРАЇНІ
}

\author{
Косохатько Б. С. \\ мazicmp \\ Iнституту права \\ Київського начіонального університету імені Тараса Шевченка \\ м. Київ, Україна
}

Динамічний розвиток суспільства та процеси глобалізації сприяють сталому розвитку суспільних відносин. Це обумовлює цифровізацію багатьох процесів, в тому числі, сфери спорту. У зв'язку з цим, із плином часу звичний для нас бокс, теніс, футбол, шахи чи інший вид спорту трансформувався в зображення на моніторі персонального комп’ютера, яке складається 3 певної математичної системи (моделі), програмного коду, графічних елементів та інших складових характерних для комп'ютерної гри. Однак, навіть побіжний огляд здобутків у сфері правового регулювання кіберспорту свідчить про практично повну відсутність відповідних досліджень [1, с. 81].

Що ж стосується часу появи електронного спорту, як явища, то на думку деяких науковців, зокрема Толмачевської Т. О. та Ткалича М. О кіберспорт (кіберспорт, комп'ютерний спорт) - це віртуальні змагання 3 комп'ютерних ігор за участю команд або окремих гравців. Розпочались неофіційні змагання з кіберспорту більше 20 років тому, коли був запущений перший мережевий шутер - Doom 2, що дозволяв залучити для одночасної гри численних геймерів. I перший офіційний турнір була влаштована в 1997 році, коли була заснована Ліга комп'ютерних гравців (CPL) в США, члени яких змагались y Quake [2, c. 90].

Тобто, ще в 1997 році з'явились певні «негласні» правила проведення кіберспортинвих турнірів, адже вступ в Лігу комп'ютерних гравців передбачав собою відповідність певним критеріям та дотримання етичних правил поведінки під час проведення змагань.

Таким чином, ще пізніше, в 2009 році було створено Міжнародну федерацію кіберспорту (електронного спорту), яка в 2020 році розробила та затвердила Міжнародні правила проведення змагань 3 електронного спорту, що створило підгрунтя для 82-ох країн-членів 
(серед яких також $є$ Україна) для розробки та затвердження власних, національних правил проведення змагань з кіберспорту.

Ще пізніше, в 2017 році, на саміті Міжнародного олімпійського комітету було озвучено думку про те, що сфера електронного спорту потребує створення певної організації, яка б могла забезпечити дотримання спортсменами так званих олімпійських цінностей (антидопінгові перевірки, правила чесної гри, тощо). Такою організацією стала згадана раніше Міжнародна федерація кіберспорту, отримавши статус учасника в Всесвітньому антидопінговому агентстві та увійшовши до складу Міжнародної асоціації спорту для всіх.

Схожа організація була створена і в Україні в 2018 році, яка стала учасником та представником нашої держави на міжнародній арені електронного спорту.

Зовсім нещодавно, а саме, в листопаді 2020 року Федерація кіберспорту України отримала статус національної, що відкрило новий шлях для розвитку кіберспорту в Україні. Також, 7 вересня 2020 року кіберспорт було визнано офіційним видом спорту в Україні [3].

Таким чином, 26 січня 2021 року Міністерство молоді та спорту України затвердило Правила змагань 3 кіберспорту (електронного спорту) [4].

Насправді, такий крок не врегульовує сферу електронного спорту повністю, однак, створює певні базові засади його існування та проведення турнірів. Також, сам документ вперше визначає поняття кіберспорту, відеогри, геймів, ЛАНу, пінгу та інших професійних геймерських визначень.

Необхідно також зазначити, що і декількома роками раніше, організаторами деяких турнірів, зокрема UUOPEN 2019 WINTER CUP 3 дисципліни «Counter-strike: Global Offensive» була спроба розробити та впровадити локальні акти, щодо проведення конкретного турніру $з$ кіберспорту, однак, така практика не стала усталеною та вимагала додаткового урегулювання з боку держави. Щоправда, згадані вище правила не суперечили вимогам чинного законодавства та навіть враховували положення цивільного законодавства, законодавства в сфері фізичної культури та спорту, а також положення та практику вимог Міжнародної федерації кіберспорту, а значить їх не можна було вважати такими, що не діють [5].

Отже, враховуючи такий стрімкий розвиток сфери електронного спорту та іï особливості необхідно зазначити, що хоч i низка нормативно-правових актів вже розроблена та впроваджена, однак, ця сфера залишається досить не врегульованою, що може створювати перешкоди для практичної реалізації вже розроблених норм. Окрім того, наразі законодавче врегулювання існує лише на рівні підзаконних 
нормативно-правових актів, хоча, на думку автора таке врегулювання має бути на рівні окремого спеціального закону або ж, (тимчасово) на рівні імплементації відповідних положень у вже існуюче законодавство.

\title{
Література:
}

1. Лавренюк О. Ю. Кіберспорт і права інтелектуальної власності. National law journal: theory and practice. 2019. C. 81.

2. Толмачевська Ю. О., Ткалич М.O. Journal of the National Academy of Legal Sciences of Ukraine, 2018. Vol. 25, № 4. P. 90.

3. Наказ Міністерства молоді та спорту України від 16.09.2020 № 1557 / Міністерство молоді та спорту України. URL: https://zakon.rada.gov.ua/rada/show/v1557924-20

4. Наказ Міністерства молоді та спорту України від 26.01.2021 № 2/5.3/21 Про затвердження «Правил спортивних змагань 3 кіберспорту (електронного спорту) / URL: https://sport.gov.ua/storage/ app/sites/16/Sport/Pravyla_zmagan/2020/pravila-kibersport.pdf

5. UUOPEN 2019 WINTER CUP «Правила проведення змагань». 2019. / URL: https://esports.ua/tournaments/3-ukrainian-university-open2019-winter-cup/rules

DOI https://doi.org/10.30525/978-9934-26-040-7-42

\section{ПРОБЛЕМИ ПРАВОВОГО РЕГУЛЮВАННЯ СУСПІЛЬНИХ ВІДНОСИН У СФЕРІ УПРАВЛІННЯ ІДЕНТИФІКАЦІЙНИМИ ДАНИМИ}

\author{
Костенко О. В.
}

доктор філософії в галузі права,

в. о. завідувача науково-дослідної лабораторії теорії і права цифррових трансформачій

науково-дослідного иеентру цииррових трансформащій і права

Науково-дослідного інституту інформатики і права

Національної академії правових наук України м. Київ, Україна

Суспільство увійшло в епоху новітньої науково-технічної революції та економічної глобалізації. Одним із ключових елементів сучасних 